\title{
Impact of Extreme Weather Events on Carbon Dioxide Emission from a Tropical Ultisol
}

\section{Uzoma KC* and Onwuka BM \\ Department of Soil Science and Meteorology, Michael Okpara University of Agriculture Umudike, PMB 7267, Umuahia, Abia State, Nigeria}

*Corresponding author: Uzoma Kingsley Chinyere, Department of Soil Science and

\begin{tabular}{c}
\hline Research Article \\
Volume 3 Issue 9 \\
Received Date: October 06, 2018 \\
Published Date: October 22, 2018 \\
\hline
\end{tabular}
Meteorology, Michael Okpara University of Agriculture Umudike, PMB 7267, Umuahia, Abia State, Nigeria, Email: kingsolisis@yahoo.com

\section{Abstract}

The impact of extreme weather events were studied in Michael Okpara University of Agriculture, Umudike, Abia State. The objective of the study was to ascertain the impacts of short drought and long drought on organic carbon content and $\mathrm{CO}_{2}$ emission. Soil samples were randomly collected at 3 sampling points at $0-15$ and $15-30 \mathrm{~cm}$ depth and subjected to induced weather condition of short drought/heavy rainfall and long drought/low rainfall. Analysis of variance was used to compare the influence of weather events on the measured soil properties at different depths and significant means were separated using least significant differences at $5 \%$ level of probability. Line graph was used to represent the impact of extreme weather event on the emission of $\mathrm{CO}_{2}$. Results showed that emitted carbon dioxide, organic carbon, total nitrogen and C:N varied with the induced weather events at 2 weeks, 4 weeks, 6 weeks and 8 weeks. Higher organic carbon, total nitrogen and C:N were recorded under short drought/heavy rainfall ( 2 and 4 weeks). The volume of carbon dioxide emitted was lower in long drought/low rainfall $\left(310 \mathrm{~cm}^{3}-345 \mathrm{~cm}^{3}\right)$ than in short drought/heavy rainfall $\left(45 \mathrm{~cm}^{3}\right.$ - $97 \mathrm{~cm}^{3}$ ) with the quality of organic matter, and the extent to which these organic substrates are protected from microbial attack by adsorption to clay surfaces and inclusion in micro-aggregates playing an important role in supressing carbon dioxide production.

Keywords: Climate Change; Weather Conditions; Rainfall; Drought; Carbon Dioxide Emission; Temperature

\section{Introduction}

Climate change has caused the intensification of both rainfall and drought changes in tropical climate zones, which in turn affect soil drying and rewetting cycles and associated processes such as soil greenhouse gas (GHG) fluxes [1].
Extreme weather conditions have large effects on water cycling and availability thereby increasing intensification of both rainfall and drought [2]. Rewetting of soils after drought and especially the first rain event after a drought can have a large effect on soil greenhouse gas emissions [3]. Large influxes of $\mathrm{CO}_{2}$ are induced during rewetting of dry soils [4]. Barton, et al. observed 


\section{Open Access Journal of Agricultural Research}

that there was a strong overall increase in $\mathrm{CO}_{2}$ emissions when dry soils were rewetted [5].

Weather conditions drive the carbon balance of soils by controlling the uptake and release of $\mathrm{CO}_{2}$ [6]. Longer dry periods in between heavier precipitation events alter the stability of large carbon pools in the soil ecosystem [1]. Soils have a great potential for carbon sequestration and storage as extreme weather conditions show decomposition in the soil and carbon accumulates over a long time [7]. Globally, there is more carbon stored in the soil than in the atmosphere and plant biomass [8]. According to Adhikari, et al. the stability of the large pool of carbon is uncertain due to human influence and changes in climate [9]. Rainfall as an extremely important factor in carbon cycling directly affect productivity, decomposition rates, methane $\left(\mathrm{CH}_{4}\right)$ production and oxidation, $\mathrm{CaCO}_{3}$ precipitation and carbon dioxide sequestration [10-13]. Soil ecosystems have large carbon pools; under certain conditions they can become a source of carbon to the atmosphere [14]. Soils also become a source of carbon when low redox potentials initiate other greenhouse gas production, such as $\mathrm{CH}_{4}$ and $\mathrm{N}_{2} \mathrm{O}$ [15].

The ratio of $\mathrm{CH}_{4}$ emissions to net $\mathrm{CO}_{2}$ uptake is an index for an ecosystem's carbon exchange balance with the atmosphere [16]. The carbon exchange balance in the soil depends on the interactions between physical conditions, microbial processes in the soil and vegetation characteristics [15]. Through heterotrophic respiration and decomposition of organic matter $\mathrm{CO}_{2}$ is released from soil increasing exponentially with higher temperatures and decreasing with soil saturation $[13,14]$.

Although tropical soils contribute to the annual global emissions of $\mathrm{CH}_{4}$, However, due to changes in extreme weather conditions carbon exchange balance of tropical soils is uncertain [16]. So there is need to study the impact of extreme weather events on $\mathrm{CO}_{2}$ emission from a tropical ultisol. Therefore, the objective of the study was to ascertain the impacts of short drought and heavy rainfall on organic carbon, total nitrogen and $\mathrm{CO}_{2}$ emission.

\section{Materials and Methods}

\section{Study Area}

The study was conducted in Michael Okpara University of Agriculture, Umudike, Abia State. The study area lies between latitudes $5027^{\prime}$ and $5029^{\prime} \mathrm{N}$ and Longitudes $7 \mathrm{o} 25^{\prime}$ and $7 \mathrm{o} 35^{\prime} \mathrm{E}$ (GPS). The area is located within the tropical rainforest belt. The climate is typically hot humid tropical with a mean annual rainfall from about $3000 \mathrm{~mm}$ along the coast to $2000 \mathrm{~mm}$ in the hinterlands. The mean annual temperature is generally uniform, ranging from $26^{\circ} \mathrm{C}$ to $28^{\circ} \mathrm{C}$. The climate is divided into the wet season (April to October) and dry season (November to March). The rainy season is characterized by bimodal rainfall pattern with peaks occurring in July and September. Relative humidity varies between 75 and 90 $\%$.

\section{Vegetation and Soils}

Umudike lies within the rain forest area of the state which has been almost completely replaced by secondary forest of predominantly rubber plantation and oil palm trees of various densities of coverage inter-mixed with tall grasses, herbaceous and woody shrubs such as Chromolaena odorata (Siam weed). The soil is composed of clay stones, sands and gravels. The predominant land use in the area as in most of the South-east is the cropping-bush fallow-cropping closed system and the major crops grown are rice, cocoa, yams, cassava, maize and vegetables. The main land-use type is arable crop production. The cropping systems are either tree-crop based or root-crop based, with the latter predominating.

\section{Soil Sampling and Experiment}

Auger soil samples were collected. The auger soil samples were collected randomly at 3 sampling points at the depth of $0-15 \mathrm{~cm}$ and $15-30 \mathrm{~cm}$ in three replications total of eighteen samples $[7,15]$. The soil samples were saturated and subjected to extreme weather conditions of short drought/heavy rainfall (2 and 4 weeks after saturation) and long drought/low rainfall (6 and 8 weeks after saturation). After saturation the samples were taken to the laboratory for analyses using standard laboratory procedures.

\section{Laboratory Analysis}

Total Nitrogen: Total Nitrogen was done by the Kjeidahl digestion and distillation method as described by Udo, et al [17].

Organic Carbon: Organic carbon was measured by the dichromate wet oxidation method of Walkley and Black [18].

\section{Determination of Carbon Dioxide}

$10 \mathrm{ml}$ of $1 \mathrm{~N}$ of $\mathrm{NaOH}$ solution was placed in a container which is connected to another container with $250 \mathrm{~g}$ of soil 


\section{Open Access Journal of Agricultural Research}

sample. Both containers were punctured and connected with a pipe. The cover of the container was sealed with gum and cello tape to make it airtight in order to avoid contamination and reaction from environment. During each titration, $5 \mathrm{ml}$ of $\mathrm{BaCl}_{2}$ was measured and mixed with $10 \mathrm{ml}$ of $\mathrm{NaOH}$ then a drop of phenolphthalein (an indicator) was added to the mixture. The phenolphthalein will turn the mixture to a visible purple/pink colour. The mixture was titrated with $1 \mathrm{~N}$ of $\mathrm{HCl}$ which will turn the purple/pink colour to colourless at the end of titration.

The volume of $\mathrm{CO}_{2}$ was calculated using the formular;

$$
\mathrm{CO}_{2}=(\mathrm{B}-\mathrm{V}) \times \mathrm{N} \times \mathrm{E}-
$$

Where $\mathrm{B}=\mathrm{HCl}$ needed for first titration,

$\mathrm{V}=\mathrm{HCl}$ needed to titrate in glass jar with treatment

$\mathrm{N}=$ normality

$\mathrm{E}=$ equivalent

\section{Statistical Analysis}

Data generated were statistically analysed. Analysis of variance was used to compare the influence of weather events on the measured soil properties at different depths and significant means were separated using least significant differences at $5 \%$ level of probability. Line graph was used to represent the impact of extreme weather event on the emission of $\mathrm{CO}_{2}$.

\section{Results and Discussion}

\section{Organic Carbon, Total Nitrogen and C: $\mathbf{N}$ of Soils Studied}

The organic carbon, total nitrogen and C:N of the soils studied are shown in Table 1 . At both depths of $0-15$ and $15-30 \mathrm{~cm}$, the soil under short drought/heavy rainfall at 2 weeks after saturation was observed to have the highest organic carbon at both depths with values 1.930 and $1.900 \%$, respectively. The soil under long drought/low rainfall at 8 weeks after saturation was observed to have the lowest organic carbon at both depths with values 1.260 and $1.240 \%$. Under total nitrogen, 2 weeks of short drought/heavy rainfall recorded the highest at both depths with values 0.161 and $0.158 \%$, 8 weeks of long drought/low rainfall was observed to have the lowest total nitrogen $(0.116$ and $0.113 \%)$ at both depths. With regards to $\mathrm{C}: \mathrm{N}$ at both depths, short drought/heavy rainfall at 2 weeks after saturation had the highest C:N value ranging from 11.988 to 12.025 , while 8 weeks of long drought/low rainfall after saturation was observed

Uzoma KC and Onwuka BM. Impact of Extreme Weather Events on Carbon Dioxide Emission from a Tropical Ultisol. J Agri Res 2018, 3(9): 000200. to have the lowest C:N values ranging from 10.862 to 10.973. With respect to both depths, long drought/low rainfall at 6 and 8 weeks after saturation were lower in organic carbon, total nitrogen and $\mathrm{C}: \mathrm{N}$, whereas short drought/heavy rainfall at 2 and 4 weeks were higher.

As shown in Table 1 and referring to depth, the means indicated no significant $(\mathrm{P} \leq 0.05)$ difference in organic carbon, total nitrogen and C:N. With respect to the weather events in both depths, the organic carbon, total nitrogen and C:N of long drought/low rainfall at 6 and 8 weeks after saturation were significantly $(p \leq 0.05)$ lower than the others. The high organic carbon and total nitrogen observed under short drought/heavy rainfall may be attributed to the microbial metabolism enhanced by the availability of accumulated substrate during the weather event [3]. Heavy rainfall could also disrupt soil aggregates, exposing physically protected organic carbon and increase the accessibility of substrate that can be rapidly mineralized [19].

\begin{tabular}{|c|c|c|c|}
\hline \multirow{2}{*}{ Weather event } & \multirow[b]{2}{*}{ OC (\%) } & \multicolumn{2}{|c|}{ Soil Properties } \\
\hline & & Total N (\%) & $C: N$ \\
\hline \multicolumn{4}{|c|}{$0-15 \mathrm{~cm}$} \\
\hline 2 weeks & 1.93 & 0.161 & 11.988 \\
\hline 4 weeks & 1.77 & 0.148 & 11.959 \\
\hline 6 weeks & 1.5 & 0.136 & 11.029 \\
\hline 8 weeks & 1.26 & 0.116 & 10.862 \\
\hline Mean & 1.615 & 0.14 & 11.46 \\
\hline \multicolumn{4}{|c|}{$15-30 \mathrm{~cm}$} \\
\hline 2 weeks & 1.9 & 0.158 & 12.025 \\
\hline 4 weeks & 1.76 & 0.145 & 12.138 \\
\hline 6 weeks & 1.49 & 0.131 & 11.374 \\
\hline 8 weeks & 1.24 & 0.113 & 10.973 \\
\hline Mean & 1.598 & 0.137 & 11.628 \\
\hline \multicolumn{4}{|c|}{ LSD $_{0.05}$} \\
\hline Weather event & 0.074 & 0.001 & 0.007 \\
\hline Depth & 0.373 & 0.132 & 0.59 \\
\hline $\mathrm{W} \times \mathrm{D}$ & 0.07 & 0.004 & 0.021 \\
\hline
\end{tabular}

$\mathrm{OC}=$ organic carbon, $\mathrm{C}: \mathrm{N}=$ carbon nitrogen ratio, $\mathrm{L} \times \mathrm{W}=$ Interaction of weather event $\times$ depth.

Table 1: Organic carbon, total nitrogen and C:N of soil under extreme weather condition studied.

\section{Emission of Carbon Dioxide}

The impact of extreme weather event on the emission of carbon dioxide is shown in figures 1 and 2. The figure showed that at the depths $0-15$ and $15-30 \mathrm{~cm}$, the 
highest volume of carbon dioxide (345 and $310 \mathrm{~cm}^{3}$ ) evolved at 2 weeks of short drought/heavy rainfall after saturation followed by 4 weeks. The lowest volume of $\mathrm{CO}_{2}$ (45 and $97 \mathrm{~cm}^{3}$ ) evolved at 8 weeks of long drought/ low rainfall followed by 6 weeks. Generally the volume of $\mathrm{CO}_{2}$ that evolved decreased with depth. These observations reflected the influence of organic carbon on the evolved $\mathrm{CO}_{2}$. As shown in fig 1 and 2, and with reference to the two depths, the values indicated that the evolved $\mathrm{CO}_{2}$ were statistically similar.

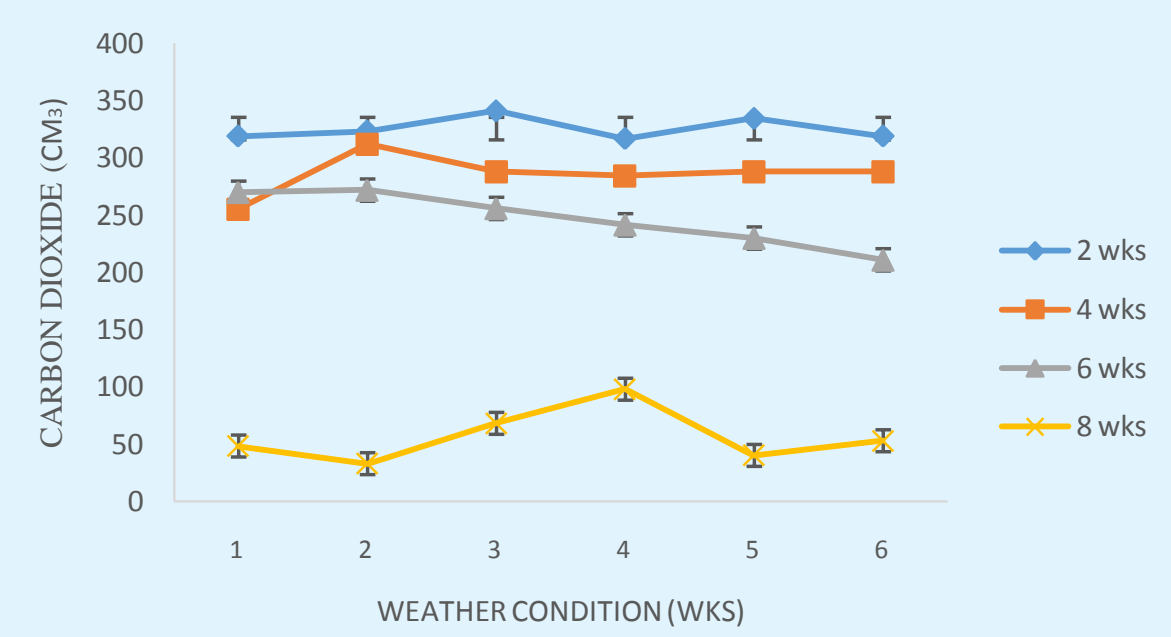

Figure 1: Impact of extreme weather event on $\mathrm{CO}_{2}$ emission at $0-15 \mathrm{~cm}$.

The variation in emission of $\mathrm{CO}_{2}$ during the induced weather events may be attributed to physical mechanism involving infiltration, reduced diffusivity and gas displacement in the soil [20]. The high volume of carbondioxide emitted under short drought/heavy rainfall were similar to the findings of Kreyling, et al [21]. He observed that increased moisture in the soil enhances microbial metabolism which increases the volume of carbon dioxide released from the soil by the soil microorganisms. Short drought/heavy rainfall increases the availability of water-soluble carbon substrates, thereby increasing the volume of carbon dioxide that evolved [22].

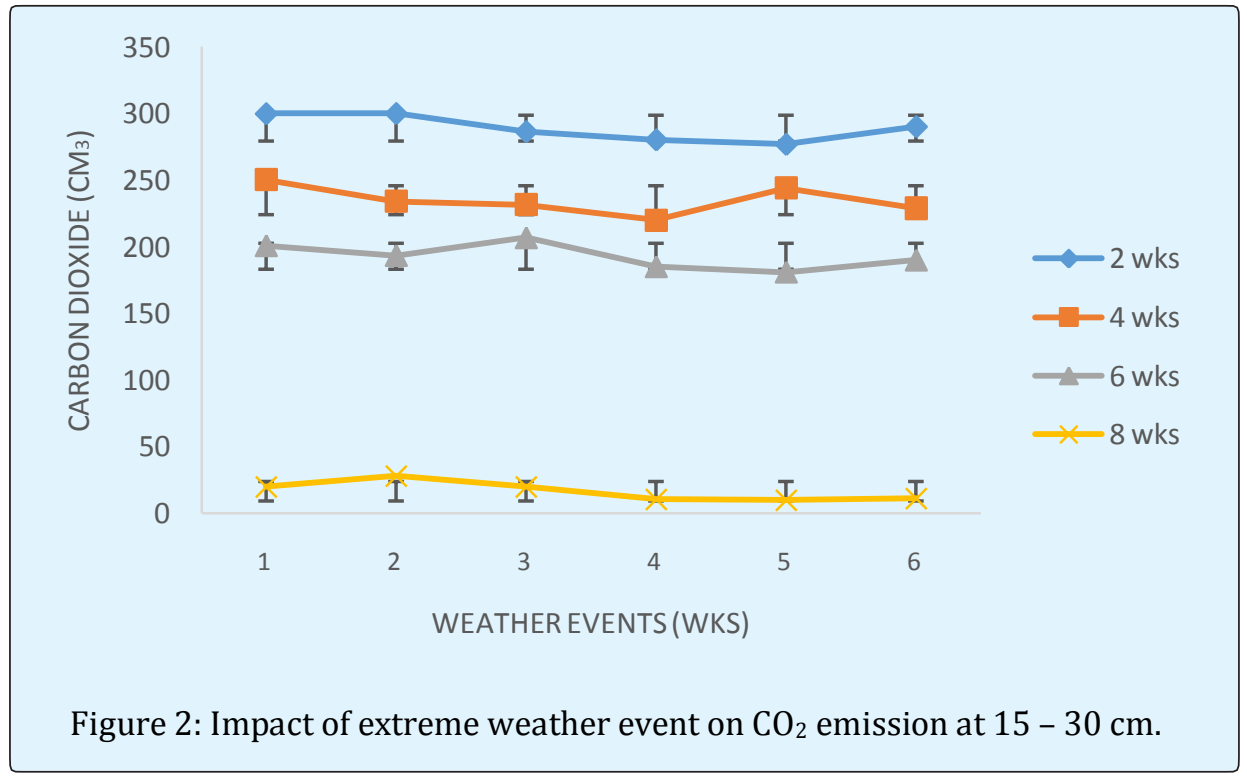

Uzoma KC and Onwuka BM. Impact of Extreme Weather Events on 


\section{Open Access Journal of Agricultural Research}

The low carbon dioxide observed under long drought/low rainfall may be as a result of the high production of $\mathrm{SO} 4$ pools through mineralization of organic sulphate and oxidation of iron sulphides which stimulate sulphate reduction and effectively suppress $\mathrm{CO}_{2}$ production [23]. The volume of $\mathrm{CO}_{2}$ evolved increased following short drought/heavy rainfall may depend on the size of the soil organic pool, the quality of organic matter, and the extent to which these substrates are protected from microbial attack by adsorption to clay surfaces and inclusion in micro-aggregates [24,25].

\section{Conclusion}

In the study of the impact of extreme weather events on the emission of carbondioxide the principal objective was to compare the impact of short drought/heavy rainfall and long drought/low rainfall on the emission of carbon dioxide from the soil.

The results of the study showed that emitted carbondioxide, organic carbon, total nitrogen and C:N varied with the induced weather events at 2 weeks, 4 weeks, 6 weeks and 8 weeks. Higher organic carbon, total nitrogen and C:N were recorded under short drought/heavy rainfall ( 2 and 4 weeks). The volume of carbon dioxide emitted was lower in long drought/low rainfall than in short drought/heavy rainfall with the quality of organic matter, and the extent to which these organic substrates are protected from microbial attack by adsorption to clay surfaces and inclusion in microaggregates playing an important role in supressing carbon dioxide production. Thus, short drought/heavy rain fall and long drought/low rain fall events could be come more critical for land-atmosphere as exchange and may be more important to incorporate in biogeochemical models. Advancements in this research field are likely to come from high frequency measurements of gas fluxes, soil microbial analyses, isotope measurements, and stronger collaborations between the process-based modelling community and the experimental scientific community.

\section{References}

1. Mosedale JR, Wilson RJ, Maclean IM (2015) Climate change and crop exposure to adverse weather: changes to frost risk and grapevine flowering conditions. PloS ONE 10(10): e0141218.

2. Durack PJ, Wijffels SE, Matear RJ (2012) Ocean salinities reveal strong global water cycle intensification during 1950 to 2000. Science 336(6080): 455-458.

3. Kim DG, Vargas R, Bond-Lamberty B, Turetsky MR (2012) Effects of soil rewetting and thawing on soil gas fluxes: a review of current literature and suggestions for future research. Biogeosciences 9: 2459-2483.

4. Borken W, Matzner E (2009) Reappraisal of drying and wetting effects on $\mathrm{C}$ and $\mathrm{N}$ mineralization and fluxes in soils. Global Change Biology 15(4): 808-824.

5. Barton L, Kiese R, Gatter D, Butterbach-Bahl K, Buck $\mathrm{R}$, et al. (2008) Nitrous oxide emissions from a cropped soil in a semi-arid climate. Global Change Biol 14(1): 177-192.

6. Malone SL, Gregory S, Staudhammer CL, Ryan MG (2013) Effects of simulated drought on the carbon balance ofeverglades short-hydroperiod marsh. Global Change Biology 19(8): 2511-2523.

7. Brevik EC, Homburg JA (2004) A 5000 year record of carbon sequestration from a coastal lagoon and wetland complex. Southern California, USA. Catena 57(3): 221-232.

8. Reddy KR, DeLaune RD (2008) Biogeochemistry of Wetlands. CRC Press, Boca Raton, FL.

9. Adhikari S, Bajracharaya RM, Sitaula BK (2009) A review of carbon dynamics and sequestration in wetlands. Journal of Wetlands Ecology 2: 42-46.

10. Heinsch F, Heilman JL, McInnes KJ, Cobos DR, Zuberer DA, et al. (2004) Carbon dioxide exchange in a high marsh on the Texas Gulf Coast: effects of freshwater availability. Agricultural and Forest Meteorology 125(1-2): 159-172.

11. Schedlbauer JL, Munyon JW, Oberbauer SF, Gaiser EE, Starr G (2012) Controls on ecosystem carbon dioxide exchange in short- and long-hydroperiod Florida Everglades freshwater marshes. Wetlands 32(5): 801-812.

12. Whalen SC (2005) Biogeochemistry of methane exchange between natural wetlands and the atmosphere. Environmental Engineering Science 22(1): 73-94. 


\section{Open Access Journal of Agricultural Research}

13. Jimenez KL, Starr G, Staudhammer CL, Schedlbauer JL, Loescher HW, et al. (2012) Carbon dioxide exchange rates from short- and long-hydroperiod

14. Webster KL, McLaughlin JW, Kim Y, Packalen MS, Li CS (2013) Modelling carbon dynamics and response to environmental change along a boreal fen nutrient gradient. Ecological Modelling, 248: 148-164.

15. Smith KA, Ball T, Conen F, Dobbie KE, Massheder J, et al. (2003) Exchange of green- house gases between soil and atmosphere: interactions of soil physical factors and biological processes. European Journal of Soil Science 54: 779-791.

16. Whiting GJ, Chanton JP (2001) Greenhouse carbon balance of wetlands: methane emission versus carbon sequestration. Tellus B-Chemical and Physical Meteorology 53(5): 521-528.

17. Udo EJ, Ibia TO, Ogunwale JA, Ano AA, Esu IE (2009) Manual of Soil, Plant and Water Analyses. Published by Sibon Books Limited, Lagos Nigeria. pp: 31-33.

18. Nelson DW, Summers LE (1996) Total carbon and organic matter in methods of soil analysis part II. In: Page AL (Eds) Chemical and microbiological properties. Am SocAgron Maidson WI pp: 359-580.

19. Sponseller RA (2007) Precipitation pulses and soil $\mathrm{CO}_{2}$ flux in a Sonoran Desert ecosystem, Global Change Biol 13(2): 426-436.
20. Xu LK, Baldocchi DD, Tang JW (2004) How soil moisture, rain pulses, and growth alter the response of ecosystemergespeisadtieshutetetermqueshattiorernal lobakophysical Biogeochem 18(4).

21. Kreyling J, Beierkuhnlein C, Elmer M, Pritsch K, Radovski M, et al. (2008) Soil biotic processes remain remarkably stable after 100 -year extreme weather events in experimental grassland and heath. Plant Soil 308: 175-188.

22. Chen S, Lin G, Huang J, Jenerette GD (2009) Dependence of carbon sequestration on the differential responses of ecosystem photosynthesis and respiration to rain pulses in a semiarid steppe. Global Change Biol 15(10): 2450-2461.

23. Soussana JF, Lüscher A (2007) Temperate grass lands and global atmospheric change: A review. Grass ForageSci 62(2): 127-134.

24. Shi WY, Tateno R, Zhang JG, Wang YL, Yamanaka N, et al. (2011) Response of soil respiration to precipitation during the dry season in two typical forest stands in the forest-grass land transition zone of the Loess Plateau. Agr Forest Meteorol 151: 854863.

25. Schlesinger WH, Andrews JA (2000) Soil respiration and the global carbon cycle. Biogeochemistry 48(1): 7-20.

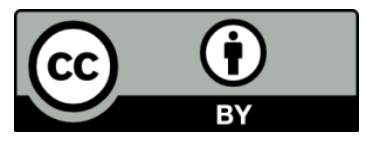

